\title{
CORPORATE GOVERNANCE IN A MARKET WITH MORALITY
}

\author{
THOMAS W. DUNFEE*
}

INTRODUCTION

Moral desires are embodied in markets. ${ }^{1}$ This article analyzes the implications for corporate governance of the existence of morality within consumer and capital markets. Analysis of the role of moral desires within markets represents a new way of looking at the long-standing debate concerning the social responsibility of corporations. The focus of this article is normative, that is, it is concerned with how managers should act. ${ }^{2}$

\section{II}

\section{THE ROLE OF THE CORPORATION: DOES IT ENCOMPASS MORAL RESPONSIBILITY?}

Competing, mutually exclusive visions exist concerning the ultimate purpose and true nature of the corporation. Variously described as communitarian

Copyright ( 2000 by Thomas W. Dunfee

This article is also available at http://www.law.duke.edu/journals/62LCPDunfee.

* Kolodny Professor of Social Responsibility, Department of Legal Studies, The Wharton School, University of Pennsylvania.

The author expresses deep gratitude to David Hess who contributed significantly to this article. Thanks also to Eric Orts, Arie Schinnar, Richard Shell, and Kevin Jackson, all of whom provided helpful and cogent comments. The author also recognizes the support of the Carol and Lawrence Zicklin Center for Business Ethics Research.

1. Moral desires, explained more fully herein, are desires pertaining to beliefs about ethically right and wrong behavior. Moral desires are equivalent to economic desires for preferred goods and services at favored prices in the sense that a person will somehow resolve competing desires through a specific decision. Thus, she may directly trade off moral and "economic" desires. The individual may require a lower price to buy goods that are inconsistent with a moral desire; for example, an animal lover may decide to buy a deeply discounted cosmetic that has been tested on animals. In that sense, the individual "prices" their morality into the decision. In turn, the decisions of an aggregation of individuals will reflect the impact of their moral desires-some refusing to buy at all, some requiring a lower price, others indifferent to the particular moral issue. This will, in turn, affect the observable price and quantity of goods and services. Thus, moral desires become embedded in markets.

2. Most of the principles developed in this article are consistent with extant corporate law. See A.A. Sommer, Jr., Comment on Dunfee, 62 LAW \& CONTEMP. ProbS. 159 (Summer 1999). Places they diverge raise an issue of whether the law should be modified. 
versus contractarian, ${ }^{3}$ the Berle v. Dodd debate, ${ }^{4}$ the shareholder paradox, ${ }^{5}$ or the separation thesis, ${ }^{6}$ these differing visions reflect conflicting political and moral preferences concerning the nature of corporations. ${ }^{7}$ Most famously, the debate is reflected in the sharply contrasting views of Milton Friedman ${ }^{8}$ and his many critics. ${ }^{9}$ Ultimately, the basis of the disagreement boils down to a monotonic versus a pluralistic view of corporate objectives. ${ }^{10}$

\section{A. The Monotonist/Pluralist Debate}

The monotonic view emphasizes maximization of shareholder wealth. "[S]hareholders claim the corporation's heart. This shareholder-centric focus of corporate law is often referred to as shareholder primacy." reduces to calculations of short-term results for shareholders. Legal mandates must be followed, but most other extra-shareholder considerations are verboten as reflecting inappropriate social or political considerations, violations of innate property rights, or, even worse, as a subterfuge that allows managers to act in furtherance of their own personal interests. Based upon a view of a corporation as a nexus of contracts, this approach eschews public intervention in support of nonshareholder obligations. ${ }^{12}$ Working from a foundation of liberty,

3. See generally David Millon, Communitarians, Contractarians, and the Crisis in Corporate Law, 50 WASH. \& LEE L. REV. 1373 (1993).

4. See generally A.A. Berle, Jr., Corporate Powers as Powers in Trust, 44 HARV. L. REV. 1049 (1931); A.A. Berle, Jr., For Whom Corporate Managers Are Trustees: A Note, 45 HARV. L. REV. 1365 (1932); E. Merrick Dodd, Jr., For Whom Are Corporate Managers Trustees?, 45 HARV. L. REV. 1145 (1932); A. A. Sommer, Jr., Whom Should the Corporation Serve? The Berle-Dodd Debate Revisited Sixty Years Later, 16 DEL. J. CORP. L. 33 (1991).

5. For a discussion of the shareholder paradox, see articles in 4 BUS. ETHICs Q. (Oct. 1994).

6. See R. Edward Freeman, The Politics of Stakeholder Theory: Some Future Directions, 4 Bus. ETHICS Q. 409 (1994).

7. Interestingly, the debate is often framed in terms of "social" responsibility, an ambiguous term open to political interpretations.

8. See Milton Friedman, The Social Responsibility of Business is to Increase Its Profits, N.Y. TIMES, Sept. 13, 1970 (Magazine), at 32; Willa Johnson, Freedom and Philanthropy: An Interview with Milton Friedman, 71 BUS. \& SOC. REV. 11 (1989).

9. For general background, see PROGRESSIVE CORPORATE LAW (Lawrence E. Mitchell ed., 1995); Ronald M. Green, Shareholders as Stakeholders: Changing Metaphors of Corporate Governance, 50 WASH. \& LEE L. REV. 1409 (1993); Lyman Johnson, The Delaware Judiciary and the Meaning of Corporate Life and Corporate Law, 68 TEX. L. REV. 865 (1990); David Millon, Redefining Corporate Law, 24 IND. L. REV. 223 (1991); Eric W. Orts, The Complexity and Legitimacy of Corporate Law, 50 WASH. \& LEE L. REV. 1565 (1993). For a bibliography of communitarian writing, which rejects the idea of shareholder primacy, see Millon, supra note 3, at 1391-93.

10. Eric W. Orts, a consistent advocate for a pluralistic view, argues that a "unidimensional economic view of corporate law is an incorrect empirical description" and that "[t]he policies underlying corporate law cannot (and presumably should not) be reduced to a unidimensional value, such as the economic objective of 'maximizing shareholders' wealth.'” Orts, supra note 9, at 1587.

11. D. Gordon Smith, The Shareholder Primacy Norm, 23 J. CORP. L. 277, 278 (1998) (challenging the relevancy of the putative norm).

12. For general background, see Frank H. Easterbrook \& Daniel R. Fischel, THE ECONOMIC Structure OF CORPORATE LAW (1991); Stephen M. Bainbridge, In Defense of the Shareholder Wealth Maximization Norm: A Reply to Professor Green, 50 WASH. \& LEE L. REV. 1423 (1993); Michael E. DeBow \& Dwight R. Lee, Shareholders, Nonshareholders and Corporate Law: Communitarianism and Resource Allocation, 18 DEL. J. CORP. L. 393 (1993); Larry E. Ribstein, The Mandatory Nature of the ALI Code, 61 GEO. WASH. L. REV. 984 (1993). 
monotonists assume that non-shareholders with an interest in corporate decisions can either explicitly contract to protect their interests, ${ }^{13}$ or can be treated as having implicitly contracted with shareholders to represent their interests. ${ }^{14}$ Milton Friedman is strongly identified with the monotonic position:

In a free-enterprise, private-property system, a corporate executive is an employee of the owners of the business. He has direct responsibility to his employers. That responsibility is to conduct the business in accordance with their desires, which generally will be to make as much money as possible while conforming to the basic rules of the society, both those embodied in law and those embodied in ethical custom. ${ }^{15}$

The pluralistic view, on the other hand, emphasizes broader constituencies or stakeholders of the corporation-variously, bondholders, suppliers, distributors, creditors, local communities, consumers, users, state and federal governments, special interest groups, etc. ${ }^{16}$ - and has even been extended by some to include a general obligation to act consistently with the general needs of society. ${ }^{17}$ This view is supported in two distinct ways. First, pluralists argue that management has an ethical obligation to act in furtherance of the interests of stakeholders. The obligation is supported by analysis that is based on a specific ethical theory (for example, Kantian ethics) or on a particularized conception of justice or rights. Advocates of ethically based, fiduciary-like obligations to stakeholders have even gone so far as to ask "[w]hat's [s]o [s]pecial [a]bout [s]hareholders?"18 Alternatively, a persuasive argument is made that firms will be more successful in achieving their primary objective of enhancing shareholder wealth by adequately reflecting stakeholder interests. ${ }^{19}$ The pluralistic view is operationalized in the academic management literature under the rubric of corporate social responsiveness. Corporate social responsiveness focuses on the ability and readiness of a corporation to respond to stakeholders. ${ }^{20}$ The lit-

13. For example, bondholders, distributors, and suppliers may easily contract with the firm to protect their own economic interests.

14. Maitland argues that the disagreement between monotonists and pluralists boils down to different empirical assumptions. See Ian Maitland, The Morality of the Corporation: An Empirical or Normative Disagreement, 4 BUS. ETHICS Q. 445, 454-55 (1994). Both sides want to recognize the selfdetermination of stakeholders. See id. Monotonists conclude that stakeholder self-determination is reflected in their explicit or implied contracts with the shareholders; pluralists disagree and argue that public policy must intervene to protect stakeholder self-determination. See id.

15. See Friedman, supra note 8, at 33.

16. See Millon, supra note 3 , at $1378-79$.

17. See id. at 1379. Interestingly, the same divergence of viewpoints is reflected in the 1994 Company Law in China, which provides a legal framework for the organization and operation of private stock companies. See Michael I. Nikkel, Note, "Chinese Characteristics" in Corporate Clothing: Questions of Fiduciary Duty in China's Company Law, 80 MiNN. L. REV. 503, 522-23 (1995). The new law sends mixed messages concerning corporate objectives and governance. See id. at 523. Article 102 provides that shareholders "shall be the organ of authority of the company," while Article 14 provides that "companies must... strengthen the establishment of a socialist spiritual civilization, and accept the supervision of the government and the public." Id.

18. John R. Boatright, Fiduciary Duties and the Shareholder-Management Relation: Or, What's So Special About Shareholders?, 4 BUS. ETHICs Q. 393, 393 (1994).

19. See generally Kenneth E. Goodpaster, Business Ethics and Stakeholder Analysis, 1 Bus. ETHICS Q. 53 (1991).

20. See generally Edwin M. Epstein, The Corporate Social Policy Process, 29 CAL. MgMT. ReV. 99 (1987); Edwin M. Epstein, The Corporate Social Policy Process and the Process of Corporate Gov- 
erature identifies strategies and processes, such as crisis management teams, that firms can implement to ensure that proper responses occur.

The debate between monotonists and pluralists has run on for decades, and, while its character and some of the specific issues have changed, it remains essentially a debate over the extent to which corporations should be governed to achieve objectives other than maximizing shareholder wealth. ${ }^{21}$ As a starting point, it should be noted that no serious writings advocate the two extreme positions on the monotonic-pluralistic continuum. At one extreme is the position that nothing should ever constrain shareholder wealth maximization. At the other extreme is the position that corporations should be managed solely to benefit non-shareholder stakeholders. Rational people do not advocate the position that corporations have an unconstrained obligation to do whatever it takes to increase shareholder wealth (for example, hiring a hitman to murder a key witness against the firm in a major product liability case). Nor do rational people expect publicly held corporations to be operated in furtherance of social or altruistic objectives with little or no concern for the interests of investors.

Where, then, on the continuum does the proper position lie? Should managers seek to balance the long-term and short-term welfare of shareholders? Prefer one to the other? Or toward the opposite end, actively seek to "balance the interests of all the firm's constituencies" in every decision, a position criticized by A. A. Sommer, Jr. ${ }^{22}$ Part of the reason for the divergence in viewpoints concerning corporate responsibility stems from the wide variety of activities that fall within its purview. Actions implicating the question of for whom the corporation is to be managed include such things as (1) engaging in corporate giving and philanthropy; (2) considering community interests in deciding on plant location or closure; (3) rejecting premiums offered in hostile takeovers; (4) making products safer than the law requires; and (5) putting in environmental controls beyond what the law requires.

Two cases help to emphasize the types of issues that underlie the monotonist/pluralist debate.

Case 1. Merck and Mectizan. ${ }^{23}$ In the late 1970s, Merck scientists discovered that ivermectin, a drug they produced to control parasites in animals, might help millions of people afflicted by onchocerciasis. This disease, known as river blindness, exists primarily in poorer countries in Africa. The

ernance, 25 AM. BUS. L.J. 361 (1987); William C. Frederick, Toward CSR3: Why Ethical Analysis is Indispensable and Unavoidable in Corporate Affairs, 28 CAL. MGMT. REV. 126 (1986).

21. The debate has been ably and thoroughly described elsewhere and it is not necessary to go into greater detail here. See generally William W. Bratton, The "Nexus of Contracts" Corporation: A Critical Appraisal, 74 CoRnell L. REV. 407 (1989); Millon, supra note 3; David Millon, Theories of the Corporation, 1990 DUKE L.J. 210; Stephen M. Bainbridge, Community and Statism: A Conservative Contractarian Critique of Progressive Corporate Law Scholarship, 82 CORNELL L. REV. 856 (1997) (book review).

22. Cindy Schipani \& Jim Walsh, The Modern Firm: Is There Liberty and Justice for All?, 28 DIVIDEND 19, 23 (1997) (quoting A.A. Sommer, Jr.)

23. For an elaborate discussion of this case and the decision process at Merck, see DAVID Bollier, BusinesS ENTERPRISE TRUST, MERCK \& CO. (A)-(D) (1991). 
disease is transmitted through black flies, whose bites introduce larvae into a victim's body. The larvae produce offspring, which cause itching so severe some people have committed suicide. Eventually, the eyes are affected, often causing blindness. Merck incurred great costs in developing the drug; these costs could not be recouped directly from those who had the disease because they were too poor to pay a profit-generating price. Ultimately, Merck spent ten years developing the drug and then decided to give the drug away without charge, and even to support financially the distribution of the drug to remote areas. The drug provides significant benefits and need only be taken orally once per year.

Case 2. Shell Oil and the Brent Spar Rig. In 1995, Shell proposed to sink a decommissioned oil rig in the North Sea. It performed an environmental impact study and obtained approval from the British government. ${ }^{24}$ Greenpeace challenged the proposed deep-sea dumping and claimed that Shell's solution of sinking the rig would cause serious environmental harm. Shell disputed the claim on scientific grounds and argued that sinking was the best available option. ${ }^{25}$ Because Shell refused to abandon its plans, Greenpeace surrounded the rig with small boats and even occupied it in $1995 .^{26}$ Due to Greenpeace's pressure and consumer boycotts, Shell foresook its sinking strategy and towed the rig to a Norwegian fiord where it remained for almost three years. ${ }^{27}$ The reversal of the original plan cost Shell considerable expense. $^{28}$ After Shell abandoned its dumping plans, independent scientists investigated and found that Shell had been correct-the environmental impact from sinking the rig would be "minimal." 29 Greenpeace admitted it was wrong on that specific claim. ${ }^{30}$

Both cases involve decisions that may impact shareholder wealth. Merck spent millions developing the drug and then incurred even greater costs by giving it away and supporting the distribution of the drug. Then-chairman Roy Vagelos indicated that he spent an enormous amount of time on the project. ${ }^{31}$ True, such an action might help Merck in hiring and retaining research scientists and could help in its relationship with certain physicians, customers, and regulators. On the other hand, few customers may even be aware of Merck's action, and the precise benefits are difficult to measure against the clear expenditures the decision cost. Assuredly, if Merck were to decide to invest half of

24. See Graeme Smith, Precedent Feared as Shell Saves £34m: Atlantic Grave Approved for Giant Oil Installation, HERALD (Glasgow), Feb. 17, 1995, at 9.

25. See Greenpeace Admits Error Against Shell, L.A. TIMES, Sept. 6, 1995, at D2.

26. See Shell Oil Platform to Become a Pier, Hous. CHron., Jan. 30, 1998, at 1B.

27. See id.

28. See id. In January 1998, after considering many disposal proposals, Shell decided to cut up the rig and make it into a pier in Norway. See id. This plan will cost Shell around $\$ 42$ million, which is more than twice what it would cost to dump the rig at sea. See id.

29. See L.A. TIMES, supra note 25, at D2.

30. See id.

31. See David Bollier, The Business Enterprise Trust, Merck \& Company 11 (1991). 
its research and development budget in likely unprofitable drugs, it would have a seriously negative impact on shareholder wealth.

Shell ineffectively considered the interests of stakeholders in its decision process and incurred costs in so doing. Its efforts were for naught because it apparently failed to evaluate correctly the likely public reaction to its decision. ${ }^{32}$ The costs Shell incurred in dealing with the project, coupled with the cost of a consumer boycott, etc., probably had a negative effect on shareholder wealth. A more accurate reading of the "moral market" it faced would have benefited shareholders.

\section{B. Does Extant Law Resolve the Monotonist/Pluralist Debate?}

Assuming that Merck explicitly considered the interests of stakeholders ${ }^{33}$ and that Shell's misreading of stakeholder concerns regarding the Brent Spar cost shareholders money, did the management of the two firms act in violation of their legal obligations? ${ }^{34}$ The answer depends on the interpretation of extant corporate law, particularly the interpretation to be given shareholder primacy. If one reads into general corporate law a dominating shareholder primacy norm that focuses only on the decision process and prohibits any consideration of impacts on stakeholders, then the answer would appear to be that both Merck and Shell acted improperly in directly considering the interests of stakeholders. If, instead, the law is interpreted to mean that managers may consider, at least

32. Shell U.K. director John Wybrew stated that even after spending four years deciding what to do with the Brent Spar-which was the technically correct decision-the company failed to understand the public's opinion and the international interest the action would attract. See Roger Cowe, Shell Chief Laments PR Failure in Move to Dump Brent Spar, GUARDIAN (London), Sept. 15, 1995, at 21.

33. This decision may have been made solely in reference to shareholder welfare with the firm calculating the likely benefits from reputation with future employees, customers, and regulators. It is not clear that Merck management considered these factors other than in vague terms; for example, research on ivermectin might lead to other discoveries. The better view is that Merck's primary motive was to help those afflicted with a horrible condition, regardless of whether it was able to realize direct profits from the product.

34. "[A] decision that may be rational on purely business grounds is nonetheless subject to invalidation if management candidly admits that its motives were other than profit-based." Kenneth B. Davis, Jr., Discretion of Corporate Management to Do Good at the Expense of Shareholder Gain: A Survey of, and Commentary on, the U.S. Corporate Law, 13 CAN.-U.S. L.J. 7, 32 (1988). Professor Bainbridge states that corporate law generally holds to the following well-known proposition from Dodge v. Ford Motor Co.:

A business corporation is organized and carried on primarily for the profit of the stockholders. The powers of the directors are to be employed for that end. The discretion of directors is to be exercised in the choice of means to attain that end, and does not extend to a change in the end itself, to the reduction of profits, or to the nondistribution of profits among stockholders in order to devote them to other purposes. ... [I]t is not within the lawful powers of a board of directors to shape and conduct the affairs of a corporation for the merely incidental benefit of shareholders and for the primary purpose of benefitting others.

Bainbridge, supra note 12, at 1424 (citing Dodge v. Ford Motor Co., 170 N.W. 668, 684 (Mich. 1919)). This statement is consistent with the traditional view that any consideration of non-shareholder interests must be rationally related to improving shareholder welfare. In some situations, the consideration of other interests - in the absence of an applicable other constituency statute-may be strictly forbidden. For example, in Revlon v. MacAndrews \& Forbes Holding, Inc., the court stated that it was inappropriate for the Revlon board to justify its actions by stating that it was protecting the corporation's noteholders when the company was clearly up for sale. See 506 A.2d 173, 182 (Del. 1985). 
in some fashion, how their decisions may benefit or harm stakeholders, then Merck and Shell acted properly so long as they considered stakeholder interests in an appropriate manner. The Merck and Shell cases demonstrate the difficulty in making a definitive assessment of the impact of stakeholder interests on shareholder wealth. Shell's actions likely injured shareholders because there were identifiable costs, but no clear-cut benefits. The Merck case is less clear because arguably, as a result of the enormous favorable publicity Merck received plus the potential opening of other markets in Africa, Merck reaped a substantial economic benefit that ultimately redounded to shareholders. The questions with Merck are whether the benefits exceeded the unquestionably significant costs, thereby producing a net benefit to shareholders, and whether such benefits were reasonably foreseeable at the time the decision was made.

Thus, the implications of the current legal regime depend to some extent on underlying assumptions concerning the likely effect of managerial consideration of stakeholder interests. The shareholder primacy norm, if fully incorporated into the legal regime, would still require that stakeholder interests be considered when doing so has a foreseeable impact upon shareholder wealth. The legal debate concerning the proper interpretation of extant corporate law reflects this empirical uncertainty, with the competing advocates working from diametrically different assumptions concerning the likely impact of acting on behalf of stakeholders. ${ }^{35}$ Unsurprisingly, much of the legal debate pertains to issues where the potential conflicts of interest between shareholder owners and agent managers are greatest. ${ }^{36}$ For example, potential conflicts abound in hostile takeovers, where managers may lose perks, even their jobs, if ownership

35. For example, consider the debate between Ronald Green and Stephen Bainbridge. Green argues that strict adherence to the monotonist view can cause-or even require-managers to ignore critical risks to stakeholders if acting on those risks would decrease shareholder wealth. See Green, supra note 9, at 1419-21 (arguing that Union Carbide's managers would have a difficult time justifying expenditures to take extra safety precautions at their plant in Bhopal, India, which suffered an accident that killed over 2,000 persons, because the risks of an accident were extremely small and the costs to improve the facility were great). Bainbridge, however, argues that management acting on behalf of stakeholders can cause many problems, including a conflict of interest problem. See Bainbridge, supra note 12, at 1446. Bainbridge also asks the question, "How would I feel about living in a world governed by the moral rules implicit in the shareholder wealth maximization norm?" and responds "pretty good." Id. "For many years, the basic rule that shareholder interests come first has governed public corporations. That rule has helped produce an economy that is dominated by public corporations, which in turn has produced the highest standard of living of any society in the history of the world." Id.

In the business ethics literature, Norman Bowie argues that there are "unenlightened" and "enlightened" Friedmanites. See Norman E. Bowie, New Directions in Corporate Social Responsibility, 34 BUS. HORIZONS 56 (1991), reprinted in ETHICAL THEORY AND BUSINESS 96, 97 (Tom Beauchamp \& Norman E. Bowie eds., 5th ed. 1997). While both types agree that a corporation exists to earn profits within certain bounds, the unenlightened manager exploits nonshareholder stakeholders to increase short-term profits, but fails in the long run due to lowered productivity and cooperation of those stakeholders. The enlightened Friedmanite manager, however, is concerned with the well-being of all its stakeholders and is able to sustain or improve long-term performance.

36. Even so, it is surprising that there has not been more debate concerning corporate philanthropy. When a corporation gives money to a senior manager's alma mater or favorite cultural charity, a conflict of interest may exist. The conflict is exacerbated when the gift results in memorializing the manager, as when a university building or an opera lounge is named for the manager even though the funds are provided by the firm. It is possible, of course, that certain donations memorializing a manager may constitute an efficient method of compensation. 
changes hands. The monotonists are properly concerned that, where interests dramatically diverge, managers may put their own well-being ahead of investors'. Managers may act egoistically, concealing their self interest with claims that they are acting in furtherance of the public good or as compelled by business ethics.

Some of the debates between the monotonists and pluralists have focused on the interpretation of state corporate constituency statutes. ${ }^{37}$ First adopted in Pennsylvania in 1983, the majority of states have since enacted them. ${ }^{38}$ Most provide that managers and directors may consider the effects of any action on some broader constituency such as employees, suppliers, customers, communities, etc. The statutes generally do not mandate that stakeholder interests be considered. Instead, they are merely permissive; management will not be liable for having demonstrably considered such interests. ${ }^{39}$ Most of the statutes were adopted in response to the threat of hostile takeovers ${ }^{40}$ and were extensively lobbied for by the management of potential target firms. ${ }^{41}$ This heritage taints their status as legitimizing a broadly pluralistic approach to corporate governance.

Significant issues exist as to how the constituency statutes should be properly interpreted and enforced. So long as they cannot be directly enforced by stakeholder plaintiffs, they will have a limited impact. ${ }^{42}$ Interestingly, they have seen surprisingly little use considering the extent to which, at least upon first impression, they appear to change the substantive law in this area. ${ }^{43}$ At this point in time, their apparent direct impact is so limited that they cannot be considered to have made a change in extant law of sufficient significance to have resolved the debate.

On the other hand, the fact that the constituency statute regime has had a limited impact does not necessarily lead to the conclusion that the law fully supports the monotonic approach. On the contrary, there is substantial support for the proposition that corporate law allows management to act in furtherance of many types of interests other than pure short-term shareholder wealth

37. See generally Eric W. Orts, Beyond Shareholders: Interpreting Corporate Constituency Statutes, 61 GEO. WASH. L. REV. 14 (1992).

38. For a list of the states with other constituency statutes, see Wai Shun Wilson Leung, The Inadequacy of Shareholder Primacy: A Proposed Corporate Regime that Recognizes Non-Shareholder Interests, 30 COLUM. J.L. \& SoC. PROBS. 587, 613 n.140, 620 n.171 (1997).

39. Connecticut is an exception in that it requires consideration of nonshareholder interests. See Conn. Gen. Stat. AnN. § 33-133(e) (West Supp. 1993); Leung, supra note 38, at 619.

40. See Orts, supra note 37 , at 24.

41. Orts notes that certain labor unions also lobbied for constituency statutes. See id. at 24-25. This fact mitigates the common wisdom that they are purely management self-interest statutes. See id.

42. For a discussion of the unenforceability of constituency statutes due to a failure to give nonshareholders standing to enforce a claim, see Rima Fawal Hartman, Situation-Specific Fiduciary Duties for Corporate Directors: Enforceable Obligations or Toothless Ideals?, 50 WASH. \& LEE L. REV. 1761, 1778-87 (1993); Gary von Stange, Corporate Social Responsibility through Constituency Statutes: Legend or Lie?, 11 HOFSTRA LAB. L.J. 461, 488 (1994); Leung, supra note 38, at 617-18; Orts, supra note 37 , at 55.

43. See generally Orts, supra note 37 , at 44, 92 (noting that corporate constituency statutes may not really be a change in corporate law). 
maximization. ${ }^{44}$ The American Law Institute's ("ALI") Principles on Corporate Governance explicitly approves of managerial actions that are "made on the basis of ethical considerations even when doing so would not enhance corporate profit or shareholder gain." 45 The most well-established use of corporate funds that does not ipso facto enhance shareholder wealth-charitable donations-is approved by statute in every state. ${ }^{46}$ In general, the business judgment rule gives management broad discretion in what interests they choose to further, so long as managers can present a rational basis for the claim that their business judgment is in the best interests of the corporation. ${ }^{47}$ In conclusion, the current legal regime does not appear to provide a definitive resolution to the monotonist/pluralist debate. Instead, as is true of so much U.S. law, its prophylactic nature allows it to evolve in a manner consistent with changing moral and political expectations.

\section{Claims That There is No Real Debate Between Monotonists and Pluralists}

Before analyzing the nature of morality that exists in markets and its implications for corporate governance, it is necessary to consider two arguments to the effect that there is not really a substantive disagreement between the monotonists and pluralists after all-that is, that when properly framed, their viewpoints converge. Neither argument, however, appears to dispose of the issue.

The first argument is based upon empirical assumptions concerning the effect of a pluralistic approach on shareholder wealth. Although shadowed in the legal literature, ${ }^{48}$ it is within the business ethics literature that the debate whether there is a true separation between obligations owed to shareholders and stakeholders has reached full extension. ${ }^{49}$ There, those who deny the existence of a separation argue that proper consideration of stakeholder interests resolves any potential conflicts because such actions will also benefit share-

44. As Solomon puts it, "[t]oday in the Anglo-American legal system, corporations have considerable flexibility in undertaking socially responsible activities." Lewis D. Solomon, On the Frontier of Capitalism: Implementation of Humanomics by Modern Public Held Corporations: A Critical Assessment, 50 WASH. \& LEE L. REV. 1625, 1626 (1993).

45. Smith, supra note 11, at 290 (quoting AMERICAN LAW INSTITUTE, PRINCIPLES OF CORPORATE GOVERNANCE: ANALYSIS AND RECOMMENDATIONS $§ 2.01 \mathrm{cmt}$. h (1994)).

46. For a list of the state statutes, see Edward Adams \& Karl Knutsen, A Charitable Corporate Giving Justification for the Socially Responsible Investment of Pension Funds: A Populist Argument for the Public Use of Private Funds, 80 IOWA L. REV. 211, 232 (1995). For a discussion of issues raised by corporate philanthropy, see Faith Stevelman Kahn, Pandora's Box: Managerial Discretion and the Problem of Corporate Philanthropy, 44 UCLA L. REV. 579 (1997).

47. See Davis, supra note 34 , at $22-23$ (stating that the law faces many hurdles in "developing meaningful limits on management's discretion to pass off voluntarism as enlightened long-term profitmaking").

48. See supra text accompanying notes 33-47.

49. The debate has centered on the existence of a "paradox" for managers who must simultaneously satisfy stakeholder claims and maximize value for the shareholder owners. See generally Kenneth E. Goodpaster \& Thomas E. Holloran, In Defense of a Paradox, 4 Bus. ETHICs Q. 423 (1994); Boatright, supra note 18; Freeman, supra note 6. Boatright, for example, seeks to resolve the paradox by suggesting that managers may consider stakeholder claims independent of shareholder interests only when management does not have a direct fiduciary obligation to shareholders. See generally Boatright, supra note 18 . 
holders. They believe that when management astutely responds to stakeholder interests, such actions either will be in the best long-term interests of shareholders or will be otherwise legally or morally compelled.

Akin to selling ethics on the ground that it enhances profitability, the view that shareholder and stakeholder interests invariably converge is based upon highly optimistic assumptions concerning potential congruence between the interests of stakeholders and shareholders. Divergence of interests between stakeholders and shareholders disappears, if at all, solely on the basis of a highly circumscribed view of the pluralist position. Only when the pluralist strategy is limited to those win-win actions-where there is a clear congruence between stakeholder and shareholder interests - can one claim to eliminate conflicting interests. In the everyday life of corporate managers, trade-offs between the interests of different corporate constituencies arise regularly. ${ }^{50}$ Business life is not somehow miraculously limited to win-win decisions. Many potentially socially responsive activities may be implemented in such a way as to have a substantial negative impact on the wealth interests of shareholders: for example, the payment of significantly above-market wages to employees. As long as that is possible, and until there is clear agreement on the parameters of proper corporate behavior, the issue-or paradox-remains relevant for our purposes.

The second argument is nicely summed up by Easterbrook and Fischel: "What is the goal of the corporation? Is it profit, and for whom? Social welfare more broadly defined?.. . Our response to such questions is: Who cares?" "E1 Easterbrook and Fischel go on to give the examples where the New York Times decides that it wants to publish a newspaper without considering shareholder returns, and a bank decides that its priority will be lending to minority-owned businesses or third world countries. So long as there is full disclosure to investors, ${ }^{52}$ they do not see a problem.

This argument requires a return to the actual language used by Milton Friedman. What exactly does Friedman mean by the phrase "while conforming to the basic rules of the society, both those embodied in law and those embodied in ethical custom"? ${ }^{53}$ Interpreted broadly, this language, particularly the reference to ethical custom, could be used to justify substantial recognition of stakeholder interests. Interpreted narrowly, the language would only reflect the truism that corporations must act in conformity with the law, and that firms need only conform with clear-cut obligations of honesty and promise-keeping. There does not appear to be support in the monotonist literature for the broad

50. The trade-offs can be between stakeholder and shareholder interests, or among stakeholder interests themselves when different groups of stakeholders hold mutually exclusive positions.

51. Easterbrook \& Fischel, supra note 12, at 35-36.

52. One can envision a risk factor in a prospectus that states "management intends to be totally indifferent to returns to shareholders."

53. Friedman, supra note 8 , at 33 . 
interpretation of this language, ${ }^{54}$ although, as might be expected, pluralists advocate such a reading. ${ }^{55}$ The narrow interpretation does not, of course, resolve the monotonist/pluralist dispute.

Whether participants in capital and consumer markets have moral desires that they do and should try to implement in their marketplace decisions is relevant to the discussion of the proper role and function of the corporation. If such morality is present in markets, then what effect should it have? Is it actually discernible in some objective sense? If so, then should firms pay some attention to morality in markets? ${ }^{56}$ Is it desirable that people act in this way? Before seeking to answer these questions and connect the conclusions to the debate about the nature of the firm, it is first necessary to discuss what is meant by the existence of morality in markets.

III

\section{MORALITY IN MARKETS}

Surely moral desires ${ }^{57}$ influence the preferences of participants in markets. Moral desires pertain to personal beliefs concerning right and wrong behavior

54. The argument given by Easterbrook and Fischel could have broad implications. To what extent do firms act in a manner consistent with their examples of the New York Times and community banks? Do they really mean to open their analysis to this extent? See Easterbrook \& Fischel, supra note 12, at 35-36. Friedman also is confusing on this issue:

I would appeal to individuals, when they are spending their own money, to look at the thing from the point of view of supporting the kind of ideas they believe in. There is nothing wrong with that, if I believe in a certain religion or a certain political view, there is nothing wrong with my spending my money to promote that. We want competition in the market for ideas as well as in the market for goods, but we don't want to get the two mixed up.

Johnson, supra note 8, at 15 (interviewing Friedman). It is not clear, at least to me, what he intends by warning against getting the two "mixed up."

55. Christopher Stone has criticized Friedman for not seriously considering those rules embodied in ethical custom, or perhaps Friedman considers them to be synonymous. See CHRISTOPHER STONE, WHERE THE LAW ENDS: THE SOCIAL CONTROL OF CORPORATE BEHAVIOR 76 (1975). For example, Friedman asks whether a corporation is to make expenditures to reduce pollution "beyond the amount that is in the best interest of the corporation or that is required by law." Friedman, supra note 8, at 33. Friedman states that making that expenditure "for a general social interest" would be spending someone else's money. Id. Stone, however, argues that a different conclusion may be reached if the rules of ethical custom are considered. See STONE, supra, at 76-77.

Norman Bowie also suggests that the rules of ethical custom could place duties on a Friedmanite manager "to not cause avoidable harms, or to honor individual stakeholder rights, or to adhere to the ordinary canons of justice." Bowie, supra note 35, at 97. Bowie, however, also cites the views of Albert Carr and Theodore Levitt, who believe that it is not the ethical customs of society in general, or "ordinary morality," that matter, but the distinct standards of business. For example, Carr likens bus iness's ethics to those of poker, where deception, concealment, and ignoring friendships is what matters.

56. "Corporations which exist solely to maximize profit become disconnected from their soul-the spiritual interconnectedness of humanity." BEN \& JERRY's, 1990 ANNUAL REPORT 2 (1991), reprinted in Solomon, supra note 44, at 1625.

57. Elsewhere I have defined moral desires as pertaining to personal beliefs concerning right and wrong. See generally Thomas W. Dunfee, The Marketplace of Morality: Small Steps Toward a Theory of Moral Choice, 8 BUs. ETHICS Q. 127 (1998).

[They] may be based in religious, ethical or sociopolitical convictions. Examples include observance of religious dietary laws or a religious-based refusal to accept any form of medical assistance. [Moral desires] may reflect a belief that it is wrong to discriminate on the basis of 
for oneself and for others and may be contrasted with purely economic desires to obtain desired goods and services at the lowest possible price. Individuals make daily trade-offs between their moral desires and other desires. Factors such as one's emotional state may affect the trade-offs in a given decision. One may pass by a homeless person on Monday and give money to the same person on Tuesday. Moral desires will often be implicated in the context of businessrelevant decisions. Moral desires may encompass refusing to do business with someone deemed to be unfair, boycotting certain firms on the basis of identification of the firm with disfavored policies, and so on.

By internally pricing moral desires against other interests, individuals make decisions influenced by moral desires that are reflected in market outcomes. That is, the quantity and prices of certain goods may be influenced by moral desires. The question for our purposes is the likely amplitude of such an effect. $^{58}$ Are there, for example, identifiable contexts in which the price and quantity of goods and services sold are influenced by moral desires? It seems quite plausible to claim that some people trade off moral desires against desires for good quality and low price in their own decisionmaking. Across the universe of those acting on the basis of moral desires, some will hold opposing moral desires (for example, those supporting animal rights and those believing in God-granted dominion over animals), and some marketplace actions based on moral desires will cancel the effect of those acting on the opposite desires. ${ }^{59}$

Moral desires may have an influence in a variety of circumstances. Familiar capital market examples include buying mutual funds that engage in social screening, or screening personal investments (for example, people refusing to own tobacco or gambling stocks). Some pension funds eschew securities of certain firms, often on the basis of social criteria that presumably reflect the pref-

gender or sexual preferences. [They] may be motivated by a hope for salvation, by an interest in leading a virtuous life, or by a more immediate need for approval by peers.

$I d$. at 129. The term "desires" is used to describe a broad set of utilities going beyond traditional economic factors. Id. The definition of preferences given by Bowles-"[p]references are reasons for behavior, that is, attributes of individuals that (along with their beliefs and capacities) account for the actions they take in a given situation"-is fully consistent with the use of the term "desires" herein. Samuel Bowles, Endogenous Preferences: The Cultural Consequences of Markets and Other Economic Institutions, 36 J. ECON. LIT. 75, 78 (1998).

58. Richard Posner appears willing to recognize the existence of some morality in the market but refuses to believe that it ever would have much of an impact: "[P] eople seem to behave morally in situations in which the costs of behaving morally are small, but to respond to incentives in situations in which those costs are large." RICHARD POSNER, THE PROBLEMS OF JURISPRUDENCE 195 (1990). Messick's observation that ethics is not the only thing that matters is unquestionably true. See generally David M. Messick, Why Ethics is Not the Only Thing that Matters, 6 BUS. ETHICS Q. 223 (1996). It is hard to imagine serious advocacy of either extreme position: Ethics never matters; only ethics matters.

59. A personal example helps to demonstrate. When the civil rights movement reached West Virginia in the early 1960s, my parents, who had patronized a cafeteria in my hometown, stopped eating there when the cafeteria remained segregated. They changed long-standing habits to reflect their support for integration. Parents of a neighbor, who rarely had eaten at the cafeteria but who supported segregation, started eating there regularly while the cafeteria was under pressure to integrate. The issue of whether a desire for segregation can be characterized as a "moral desire" is discussed briefly infra at note 68 . 
erences of their beneficiaries. ${ }^{60}$ Although the total impact of all forms of screening is hard to measure, the Social Investor Forum estimated that the amount invested in socially screened mutual funds increased from $\$ 650$ billion in 1996 to $\$ 1.18$ trillion in $1997 .^{61}$ Some critics of socially screened investing assume that there is, or should be, a single, universal definition of socially responsible investing. For example, Hylton points out a "persistent inability on the part of all participants in the debate to develop a simple, coherent definition of what is meant by socially responsible investing," while noting with some dismay that many funds purporting to engage in the practice have little in common. ${ }^{6}$ Hylton's dismay is consistent with the idea that there is a single exogenous definition of what constitutes socially responsible behavior. That is not the way, however, that the market works. With adequate disclosure, some investors will be influenced by their own moral desires. Thus, one person might buy a fund that eschews firms that violate the MacBride Principles in Northern Ireland, while another investor might be totally indifferent to the MacBride issue and, instead, might detest firms that cater to those with addictions. The latter investor might buy a screened fund that excludes tobacco and gambling stocks, yet hold securities of firms that violate the MacBride principles.

Similar actions are found in consumer markets. Consumers support their desires for a clean environment by paying more for pollution-reducing gasoline even though they are not required by law to purchase it. ${ }^{63}$ Similarly, sales of Star Kist tuna increased when it switched to suppliers that protected dolphins, even though the switch caused higher prices. ${ }^{64}$ Firms such as the Body Shop, Tom's of Maine, and Ben \& Jerry's target the moral desires of potential customers by engaging in social-cause marketing. Such firms seek to identify with particular social causes, such as saving whales, as a means of attracting consumers who want to support those causes. Consumers may choose to do business with them solely on the basis of an assumed alignment of moral preferences. They may even be willing to pay a higher price or accept less desirable goods to support a favored cause through their purchasing decisions. The recent growth of these strategies is reflected in the $\$ 535$ million that corporations donated in

60. So long as there is full disclosure and the screening is demonstrably consistent with the overall desires of the beneficiaries, it is consistent with the idea of morality in markets, and as will be argued, infra, a highly desirable phenomenon. Individuals who do not want social policies to govern how their pension funds are invested can leave the firm or work to modify the pension fund's investment policy.

61. See R. Bruce Hutton et al., Socially Responsible Investing: Growing Issues and New Opportunities, 37 BUS. \& SOC. 281, 288 (1998).

62. Maria O'Brien Hylton, "Socially Responsible” Investing: Doing Good Versus Doing Well in an Inefficient Market, 42 AM. U. L. REV. 1, 2 (1992).

63. See Harold H. Kassarjian, Incorporating Ecology into Marketing Strategy: The Case of Air Pollution, 35 J. MARKETING 61, 65 (1971). "Within six weeks after the introduction of the [pollutionreducing] gasoline, more than half of the population had paid an additional two to 12 cents per gallon to try the new brand." Id.

64. See Robert H. Frank, Can Socially Responsible Firms Survive in a Competitive Environment?, in CODES OF CONDUCT: BehaVIORAL RESEARCH inTO Business ETHICS 86, 95 (David M. Messick \& Ann E. Tenbrunsel eds., 1996). 
1997 to well-known charities in exchange for the right to associate their names with the charities' causes in marketing campaigns. ${ }^{6}$

Consumers may also participate in boycotts to show disapproval of a firm's actions. Examples include negative consumer reaction to Shell's failure to intercede to prevent the execution of Ken Saro Wiwa in Nigeria, Nestles' marketing practices to sell infant formula in developing countries, and Exxon's handling of the Valdez oil spill. Daniel Kahneman et al. found that individuals were willing to incur additional costs, such as traveling a greater distance, to punish a retailer who, in their opinion, acted unfairly by trying to take advantage of scarcity. ${ }^{66}$

Robert Frank found similar effects in labor markets. Frank identified the existence of a compensating wage premium for less altruistic jobs. ${ }^{67}$ Frank gives as examples the large salary gaps between profit and nonprofit jobs, corporate and public interest law, and expert witnesses for the tobacco companies and those for the opposition public interest groups. ${ }^{68}$ Job searchers may select among competing employment offers on the basis of the perceived moral environment of the prospective employers.

Thus, the claim that there is morality in markets in the sense that some market participants are influenced by their own moral desires seems easily supportable. $^{69}$ For most markets, it may be that price and quality considerations dominate, but, for certain markets, moral desires may dominate. Attitudes about morality may influence decisions about such products and services as furs, certain types of drugs, prostitution, or even the scalping of sports and entertainment tickets. $7 \mathrm{~B}$.

65. See Thomas A. Fogarty, Corporations Use Causes for Effect, USA TODAY, Nov. 10, 1997, at

66. See Fairness as a Constraint on Profit Seeking: Entitlements in the Market, 76 AM. ECON. REV. 728, 735 ( 1986).

67. See Frank, supra note 64, at 96.

68. Frank also contrasts attitudes toward being a lawyer for the National Rifle Association ("NRA") and being a lawyer for the Sierra Club. See id. This observation is apparently based on the assumption that most people would prefer to work for the Sierra Club than the NRA. But there may be people whose moral desires favor the right to own and use guns and who, consistent with the approach taken in this article, would be willing to work for the NRA for a lower salary than they would require to work for Handgun Control. Moral desires come in all hues and tones in the overall market, and, within the overall market, the effect may be to cancel out the impact of particular competing desires. Some "moral" desires in the market, such as the example given earlier of a preference for racial segregation, may violate universal moral principles, or hypernorms as discussed infra. In many instances they will be canceled out by contrary preferences, as was the case in the example of civil rights in West Virginia; however, even if they come to dominate and become a community norm, they are nonetheless illegitimate because they violate hypernorms.

69. I am not making the claim that morality itself should be viewed as the output of a market. There are some interesting possibilities, however, in thinking of morality in market terms. There may be certain moral issues, such as the use of severance packages in downsizing, the use of animals in medical research, and even abortion, where the input of competing moral desires operates in a manner similar to if not totally congruent with a market. In such a context, one could consider the demand factor to be a demand for resolution of the particular moral conflict. The supply is the competing moral desires as reflected in a variety of capital, consumer, labor, and political market contexts. The outcome is the number of abortions, the typical size of severance packages, the number of animals used in research, and so on. These ideas are tentatively explored in Dunfee, supra note 57. 
The use of economic analysis to consider various dimensions of human interaction reinforces the claim that there is a discernible morality in markets. Gary Becker is a leading practitioner of this relatively new art. ${ }^{70}$ He uses a very broad analysis of tastes and preferences, including such things as personal and social capital pertaining to future consumption, ${ }^{71}$ a discount of the future, ${ }^{72}$ and desires for things such as religiosity or health. ${ }^{73}$ In so doing, Becker explicitly recognizes that individuals may attempt to satisfy what are here called moral desires, in their decisions concerning current consumption. Even some of the assumptions underlying Richard Posner's controversial analysis of human sexuality and sexual practices is consistent with this core idea. ${ }^{74}$

IV

\section{THE IMPLICATIONS OF MARKETPLACE MORALITY FOR CORPORATE GOVERNANCE}

If marketplace morality has discernible effects on relevant consumer and capital markets, then even a straightforward monotonic analysis requires that management consider it carefully. Otherwise, managers will not maximize the potential return to shareholders because they will fail to appreciate fully the preferences of investors and consumers. However, for our purposes, the ultimate question is whether there is discernible marketplace morality that requires management to take actions inconsistent with the monotonic approach to corporate governance.

\section{A. Does Marketplace Morality Support Monotonists or Pluralists?}

Before answering the ultimate question, we must first determine whether marketplace morality supports either the monotonic or pluralistic approach to corporate governance. ${ }^{75}$ If it does, then the framework of analysis is determined. If there is support for the monotonist position, then the straightforward norm of shareholder primacy is ethically required. If, instead, there is support for a pluralist position, then more analysis is required to determine which pluralistic vision is supported by marketplace morality. Survey data on this point is limited, although some appears to support the pluralistic position. One mas-

70. See generally GARY S. BECKER, ACCOUnting FOR TASTES (1996); GARY S. BECKER \& Guity NASHAT BECKER, THE ECONOMICS OF LIFE (1997).

71. Personal capital refers to "relevant past consumption and other personal experiences that affect current and future utilities," while social capital refers to "the influence of past actions by peers and others in an individual's social network." BECKER, ACCOUNTING FOR TASTES, supra note 70, at 4.

72. See id. at 10-12.

73. See id. at 5-6.

74. See generally Richard A. POSNER, SEX AND REASON (1992).

75. One could engage in a political analysis to determine whether the political system has somehow dictated that pluralistic values should be observed. It is well beyond the scope of this article, but there is obviously a question of how effective the political system is in giving effect to the moral desires of any relevant group of people. 
sive study of more than 15,000 middle managers from twelve countries posed the Friedman question directly:

Which of these opinions do you think most other people in your own country would think better represents the goals of a company, (a) or (b)?

(a) The only real goal of a company is making profit.

(b) A company, besides making profit, has a goal of attaining the well-being of various stakeholders, such as employees, customers, etc. ${ }^{76}$

In no country did a majority of managers agree with the first answer. The United States had the highest percentage of agreement at forty percent. $^{77}$ These results are consistent with an earlier survey which found that managers at all levels consistently ranked the general public as more important than shareholders. ${ }^{78}$

It is common for U.S. and global business groups representing senior managers to directly reject the Friedman formulation of the monotonic approach. For example, the United States Business Roundtable has stated that "[c]orporations are chartered to serve both their shareholders and society as a whole... . The other stakeholders in the corporation are its employees, customers, suppliers, creditors, the communities where the corporation does business, and society as a whole." offered by the global Caux Round Table stress stakeholder obligations throughout by emphasizing responsibilities toward customers, employees, suppliers, social/political communities, and even, controversially, competitors. Monotonists might be expected to question whether these statements represent genuine positions of significant business groups and to claim that the statements are merely motivated by a public relations strategy. ${ }^{81}$ One would expect that the general public would have an even stronger preference against the monotonic positions, preferring instead that corporate managers seek to act consistently with unambiguous popular morality.

A precise, uncontroversial resolution of the relationship between marketplace morality and the monotonist/pluralist debate is probably not feasible at this time. Furthermore, as has been stressed, marketplace morality may change over time. Nor is a definitive resolution necessary to our analysis. Instead, it is possible to identify alternative frameworks, depending on the nature of marketplace morality within a given community.

76. Charles Hampden-Turner \& Alfons TrompenaArs, The Seven Cultures of CAPITALISM 32 (1993) (order of question and answers is reversed in original).

77. See id.

78. See Barry Z. Posner \& Warren H. Schmidt, Values and the American Manager: An Update, 26 CAL. MgMt. ReV. 202, 207 (1984).

79. Orts, supra note 37 , at 21.

80. See Caux Round Table, Principles For Business (1995). The Caux Round Table is an organization comprised of very senior executives from Asia, Europe, and the United States. It takes its name from its practice of holding its annual meetings at the Mountain House in Caux, Switzerland.

81. Or they might see them as part of an agency problem in which senior management is seeking cover for self-serving violations of its obligations to shareholders. 


\section{B. Justifications for Respecting Marketplace Morality}

Two basic justifications for incorporating the consideration of marketplace morality into corporate governance are offered-one normative and one instrumental. First, the normative justification relies upon a hypothetical global social contract that requires managers to identify and act consistently with legitimate ethical norms found in the communities in which their firms operate. Thomas Donaldson and I have elaborated at length upon this social contract in a theory we have called Integrative Social Contracts Theory ("ISCT"), which is grounded in the familiar idea that social norms serve as a foundation for rules of behavior in communities. Donaldson and I hypothesize that rational global contractors seek a moral background essential to sustain productive business, and, at the same time, retain the ability to select their own values and moral rules to the greatest extent possible. There are four key terms in the global social contract. The first two are as follows: "Local economic communities possess moral free space in which they may generate ethical norms for their members through microsocial contracts. Norm-generating microsocial contracts must be grounded in consent, buttressed by the rights of individual members to exercise voice and exit." ${ }^{, 3}$

Communities are at the core of the macrosocial contract. A community is defined in ISCT as a self-defined, self-circumscribed group of people who interact in the context of shared tasks, values, or goals, and who are capable of establishing norms of ethical behavior for themselves. Corporations, subsidiaries, even departments or informal units within an organization, along with partnerships, professional groups, trade associations, and nation states may all be ISCT communities in the context of a given ethical decision. In focusing on communities, ISCT recognizes that norm-governed group activity is a critical component of economic life.

A major impact of ISCT is to establish that norms are obligatory for dissenting members of communities when an authentic norm has been identified and when it satisfies the other requirements of ISCT given below. The obligation stems from the consent given when one acts as a member of a community, perhaps by accepting the benefits of the community environment. However, ISCT imposes some additional requirements on the operation of the community. The community must respect the right of members to withdraw or exit from group membership. Thus, a dissenting member of a community who is distressed about a particular authentic norm may elect to leave the community.

82. See, e.g., Thomas Donaldson \& Thomas W. Dunfee, TiEs That Bind: A Social CONTRACTS APPROACH TO BUSINESS ETHICS (1999) [hereinafter DONALDSON \& DuNFEE, TIES THAT BIND]; Thomas Donaldson \& Thomas W. Dunfee, Integrative Social Contracts Theory: A Communitarian Conception of Economic Ethics, 11 ECON. \& PHIL. 85 (1995) [hereinafter Donaldson \& Dunfee, Communitarian]; Thomas Donaldson \& Thomas W. Dunfee, Towards a Unified Conception of Business Ethics: Integrative Social Contracts Theory, 19 ACAD. MGMT. REV. 252 (1994) [hereinafter Donaldson \& Dunfee, ISCT]. The description of ISCT used here tracks closely with Thomas W. Dunfee, International Business Ethics, in THE IEBM HANDBOOK OF INTERNATIONAL BUSINESS 264 (Rosalie L. Tung ed., 1999).

83. Donaldson \& DUNFEe, TiEs That BInd, supra note 82, at 41-43. 
Employees may, and generally should, leave a corporation whose values are significantly at odds with important personal values. Similarly, an individual should have the opportunity to exercise voice within the community. This notion is consistent with much of the organizational justice literature documenting employee attitudes about procedural justice. Often, some form of voice (for example, the right to a hearing to present one's side of the case or to confront an accuser) is critical to employee judgments that a firm has acted justly. A norm meeting these requirements is considered "authentic."

To avoid excessive relativism, and with the recognition that communities do indeed develop authentic norms supporting race- and gender-based discrimination as well as other problematic practices, it is assumed in ISCT that the original contractors wish to recognize a limited set of universal principles that constrain the relativism of community moral free space. Accordingly, the third term of the macrosocial contract states as follows: "In order to become obligatory (legitimate), a microsocial contract norm must be compatible with hypernorms." Hypernorms are defined as "principles so fundamental to human existence that ... we would expect them to be reflected in a convergence of religious, philosophical, and cultural beliefs." ${ }^{\circ 6}$ As expressed by Michael Walzer, they would be a thin "set of standards to which all societies can be heldnegative injunctions, most likely, rules against murder, deceit, torture, oppression, and tyranny." 87

Hypernorms thus bind the moral free space of communities. If, for example, a hypernorm prohibiting coarse bribery exists, ${ }^{88}$ then any authentic norm recognizing bribery among, for example, a community of corrupt government officials in Russia is not legitimate ipso facto. A norm meeting the hypernorm requirement is considered "legitimate." ${ }^{, 9}$ However, hypernorms do not provide a complete bounding of the moral free space of communities. There may still be a conflict between two or more norms that are legitimate. Accordingly, the fourth term of the macrosocial context provides that "[i]n cases of conflicts among norms satisfying microsocial contract terms $1-3$, priority must be established through the application of rules consistent with the spirit and letter of the macrosocial contract." 90

Often, multiple, legitimate norms that are applicable to the same ethical judgment come into conflict. This may happen when a transaction crosses two distinctly different communities, as is often the case in global business transactions. Cultures may have quite different norms concerning what constitutes

84. Authentic norms are discussed infra Part III.C.

85. DONALDSON \& DunfeE, TIES ThAT BIND, supra note 82, at 44.

86. Donaldson \& Dunfee, ISCT, supra note 82, at 265.

87. Moral Minimalism, in From the Twilight of Probability: Ethics and Politics 3, 9 (William R. Shea \& Antonio Spadafora eds., 1992).

88. See Thomas W. Dunfee et al., Social Contracts and Marketing Ethics, 63 J. MARKETING 14 (July 1999).

89. Determining what is a hypernorm is discussed infra Part III.C.

90. DONALDSON \& DUNFEE, TIES THAT BIND, supra note 82, at 46. 
appropriate corporate behavior. For example, in the United States, corporate philanthropy is well established, but in certain Asian countries, corporate charity may not be considered proper. If both the pro- and anti-philanthropy norms are clearly authentic, then both are presumably legitimate because neither violates a hypernorm. How is this conflict to be resolved? To resolve problems of this type, ISCT specifies a loose set of six priority rules:

(1) Transactions solely within a single community, which do not have significant adverse effects on other humans or communities, should be governed by host community norms;

(2) Community norms for resolving priority should be applied, so long as they do not have significant adverse effects on other humans or communities;

(3) The more extensive the community which is the source of the norm, the greater the priority which should be given to the norm;

(4) Norms essential to the maintenance of the economic environment in which the transaction occurs should have priority over norms potentially damaging to that environment;

(5) Where multiple conflicting norms are involved, patterns of consistency among the alternative norms provide a basis for prioritization; and

(6) Well-defined norms should ordinarily have priority over more general, less precise norms.

The implications of this contractarian analysis for corporate governance in a market with morality are relatively straightforward. Managers have an obligation, based in social contract, to respond to mandatory marketplace morality reflected in legitimate, authentic norms. Where marketplace morality is instead permissive, managers are acting within moral free space and have a range of choice as to how they may act. In all actions, managers are bound by hypernorms reflected in manifest universal norms or principles. Obligations thus may vary on the basis of specific authentic norms. Before spelling out the implications for corporate governance, we must briefly consider the instrumental justification for paying attention to marketplace morality.

Even if marketplace morality supports the monotonic position, the presence of morality within consumer and capital markets still has implications for the committed monotonic manager. If a manager fails to react to conspicuous signs of moral expectations for her firm, she may implement strategies doomed to underperform or even produce losses for the firm. Both outcomes will have a negative impact on shareholder wealth. Consider again the example of the experience of Shell with the Brent Spar. Shell's managers may have detracted from shareholder wealth by failing to anticipate the impact of marketplace morality. They may have thought that the issue of how to dispose of the rig was merely a technical one. If so, all they had to do was to explain the science of the decision to relevant stakeholders. It turned out to be a very different type of issue. A sufficiently significant portion of the public chose to believe Greenpeace and thereby supported actions that prevented Shell from carrying out its

91. Donaldson \& Dunfee, Communitarian, supra note 82, at 105-06. 
plans. Public support for Greenpeace occurred even though Greenpeace was ultimately proven wrong on critical scientific facts. One explanation for this seemingly irrational result pertains to the nature of trust, particularly in reference to decisions affecting the natural environment. A series of controversial incidents over time involving Shell, ${ }^{92}$ coupled with the potential of a conflict of interest on the part of Shell that stood to profit from actions harmful to the environment, apparently caused many people to conclude that Shell was acting in a manner inconsistent with their moral desires.

A similar analysis may be used in reference to the tobacco companies and to Exxon's handling of the Valdez oil spill. The case may be made that the tobacco companies failed to discern changing public attitudes about their product, particularly in regard to rather cavalier industry attitudes about encouraging teenage smoking. R. J. Reynolds's Joe Camel campaign provoked enormous controversy as being obviously targeted toward children. In spite of the protestations of the industry that they had little to do with it, by the mid1990 s, young smokers were the only group in the United States among whom smoking was increasing. ${ }^{93}$ The enormous costs ultimately incurred by the companies as a result of political and legal actions might have been significantly smaller had the companies acted more responsively when it became clear that public sentiment was changing.

The infamous grounding and subsequent oil spill of the Exxon Valdez off the shores of Alaska is a well-known corporate disaster. The manner in which Exxon management responded to the spill has been significantly criticized, ${ }^{94}$ and Exxon was, for a while, the poster child for how not to manage a crisis. The company allowed unsafe practices, was not prepared to handle quickly a spill of that type and magnitude in Alaska, issued contradictory statements de-

\footnotetext{
92. Shell has been involved in many controversial incidents; a few of the major events are listed here. For a discussion of Shell's public relations history, see Andrew Rowell, Unlovable Shell, the Goddess of Oil, GUARDIAN (London), Nov. 15, 1997, at 23. After World War II, Shell manufactured pesticides on a site in the Rocky Mountains that the U.S. military had previously used to make nerve gas. In 1960, a game warden notified Shell of harm to local wildlife that was believed to be caused by Shell's activities, but Shell continued operations in the area until 1982. In 1988 and 1989, Shell operations caused a discharge of 440,000 gallons of oil into the San Francisco Bay and 150 tons of crude oil into the River Mersey in the United Kingdom. Also in the 1980s, Shell refused to comply with a U.N. and OPEC boycott of oil supplies in South Africa. See Yvette Cooper \& David Orr, When the People Take on an Oil Giant, INDEPENDENT (London), Nov. 14, 1995, at 15. Beginning in the early 1990s, the Ogoni people in Nigeria demanded that Shell compensate them for damage done to their homeland caused by Shell's operations. See Rowell, supra, at 23. This situation became a major international event in 1995, shortly after the Brent Spar incident, when the Nigerian military government executed Ken Saro-Wiwa, an Ogoni leader protesting Shell's activities, and eight others. The eight had been convicted by the Nigerian government for the murder of opposition tribal leaders. The Nigerian action was very controversial and drew worldwide condemnation. Shell failed to intervene or condemn the actions of the Nigerian government, and many alleged that Shell had supported the military regime. See Cooper \& Orr, supra, at 15.

93. See S. Prakash Sethi \& Paul Steidlmeier, Up Against the Corporate Wall: Cases IN BUSINESS AND SOCIETY 346 (6th ed. 1997).

94. See Beth Goodpaster, Case: Exxon Valdez: Corporate Recklessness on Trial, in POLICIES AND PERSONS: A CASEBOOK IN Business ETHICS 369 (Kenneth E. Goodpaster \& Laura L. Nash eds., 3d ed. 1998).
} 
fending its actions, did not send senior leadership to the site immediately afterward, and was accused of appearing arrogant about its responsibility for the incident. ${ }^{95}$ Exxon paid more than $\$ 3.4$ billion in direct charges, was subject to boycotts (for example, some holders cut up their credit cards and returned them to the company), and ultimately was assessed more than five billion dollars in punitive damages in a 1994 lawsuit. ${ }^{96}$ Again, the failure to respond adequately to the moral desires in the market cost shareholders.

\section{Principles for Respecting Marketplace Morality}

The following four guiding principles for managers derive from the normative and instrumental justifications for respecting marketplace morality. They are not based on assumptions concerning the specific nature of marketplace morality. Instead, they are open to whatever output occurs with an expectation that marketplace morality will change over time. The four principles are the following:

(1) There is a presumption that all corporate actions must be undertaken to maximize shareholder wealth;

(2) Managers must respond to and anticipate existing and changing marketplace morality relevant to the firm that may have a negative impact on shareholder wealth;

(3) The presumption in Principle One may be rebutted where clear and convincing evidence exists that marketplace morality relevant to the firm would justify a decision that cannot be shown to maximize shareholder wealth directly; and

(4) Managers must act consistently with hypernorms (manifest universal norms and principles).

Principle 1. Maximize Shareholder Wealth as a First Duty. This principle is supported in law, agency principles, property rights, and moral analysis of the corporation. $^{97}$ It is the core of the monotonic approach. Yet the basic obligation to generate profits for shareholders is recognized in most pluralistic approaches. Note that Principle One requires shareholder wealth maximization as a first duty, not as the sole duty. Remembering Milton Friedman's qualification-"while conforming to the basic rules of the society, both those embodied in law and those embodied in ethical custom" "-even committed monotonists recognize it only as a first duty, albeit a strong and dominating one. The dispute between the monotonists and pluralists concerns the circumstances and extent to which the first duty may be overridden, not whether there is such a duty. This underlying agreement is recognized here by

\footnotetext{
95. See id.

96. See Keith Schneider, Exxon is Ordered to Pay \$5 Billion for Alaska Spill, N.Y. TiMES, Sept. 17,

97. See supra Part II.

98. See supra text accompanying note 15 .
} 1994, at 1. 
creating a rebuttable presumption in favor of shareholder wealth maximization. The next two principles specify the circumstances in which marketplace morality may overcome the presumption. The fourth principle then indicates the limits placed on both marketplace morality and shareholder wealth maximization by manifest universal ethical norms and principles.

Principle 2. Respond to Market Signals Concerning Moral Preferences. The discussion thus far has emphasized how the interaction between marketplace morality and corporate decisionmaking can have either a beneficial or negative impact on shareholder wealth. To the extent that this is true, the critical issue becomes how to identify marketplace morality with sufficient specificity to enable responsive strategies. The search must begin with an identification of the relevant communities in which marketplace morality will be contained. The key place to look is in markets directly relevant to the firm. These would include, for example, consumer markets targeted by the firm, labor markets from which the firm hires, and capital markets tapped by the firm.

The second question is what to look for. Marketplace morality will be reflected in what was described earlier as authentic norms. ${ }^{99}$ Authentic norms represent a consensus pertaining to the propriety of particular actions based on aggregate attitudes and behaviors of individuals within a particular community. An example is the norm held by the television industry, and also apparently the public, that firms selling hard liquor should not advertise on television. This norm was observed for many years through the voluntary behavior of the industry. However, as demonstrated when Seagram broke with the long-standing norm and advertised on television in 1996, such norms may be malleable and susceptible to change.

Donaldson and I suggest the following process for identifying important moral norms:

An authentic norm may be presumed to exist on the basis of the following:

(1) Many people in the community believe it exists and are able to express it in words;

(2) Inclusion in a formal professional code;

(3) Inclusion in a corporate code;

(4) Commonly listed in the media as an ethical standard for the relevant community;

(5) Commonly referred to as an ethical standard by business leaders; and

(6) Identified as a standard in competent opinion surveys.

The more sources which support a particular candidate for an authentic norm, the stronger the presumption in its favor. The presumption in favor of authentic norm status may be overcome on the basis of:

(1) Evidence of substantial deviance from the putative norm;

99. See supra Part IV.B. 
(2) Evidence of an inconsistent or contrary norm in the same community;

(3) Evidence of coercion relating to the norm within the relevant community; and

(4) Evidence of deception influencing the emergence or evolution of the norm.

The more proxies supporting the existence of an authentic norm, the stronger the contrary evidence required to conclude that the norm is, in fact, ersatz.

The type of evidence required for these judgments will generally be commonly known and readily available. It will not require an elaborate amount of research. The presumption will not result in perfect judgments, and there is always some chance of either failing to identify a genuine authentic norm, or of pronouncing ersatz norms to be authentic. On the other hand, we would expect that the prima facie norms recognized on the basis of the presumption will generally hold up if subjected to an ex post test. Nor do such tests have to be complicated, expensive, or elaborate. Common techniques such as the use of focus groups chosen as a valid sample of the target community may be used to test the authenticity of putative norms. ${ }^{100}$

One result of this search may be to discover that the various markets relevant to a given firm send conflicting signals regarding moral preferences. For example, the morality of the firm's investors may be at odds with the market morality within labor or consumer markets relevant to the firm. Such a conflict may be resolved by evaluating the issue in the context of the morality existing in a broader market that subsumes the competing sub-markets. Thus, if the issue is workplace or product safety, the broader political community may have discernible, clear-cut authentic norms that would establish a priority among any competing norms in the sub-market. If no resolution is provided by looking to a broader community, then management must assess the relative importance of the different markets in the context of the firm's ability to achieve its goals. There should not be a serious problem of incommensurability because, under Principle Two, the ultimate test is the welfare of shareholders.

It should be stressed that marketplace morality often indicates profitmaking opportunities for the firm. Taking steps to align the firm with the moral desires of important consumer or labor market groups may result in enhanced sales or recruiting. Realizing that judgments concerning the profit potential of such opportunities are not crystal clear, particular leeway should be given to managers who experiment with reaching these special markets.

There may be circumstances in which a decision may initially appear to maximize shareholder wealth, such as Exxon taking a hard defensive position immediately after the Valdez incident, or R. J. Reynolds actively seeking new smokers by finding ways to encourage pre-teens to experiment with smoking. But the action, when considered against evidence of marketplace morality, foreseeably may hurt shareholders in the long run. In such circumstances, managers have an obligation to search for evidence of conflicting morality and to bring their actions into conformity with that of dominant authentic norms. Again, here, the test is the ultimate welfare of shareholders.

100. Donaldson \& DunfeE, TiEs That Bind, supra note 82, at 105-06 (numbered list different from bulleted list in original; changes reflect journal conventions). 
Principle 3. Justify Actions that Fail to Maximize Shareholder Wealth. Next, one considers the pluralist arguments that managers have an ethical or social obligation to act to satisfy objectives other than maximizing shareholder wealth. Following the principles presented here helps to resolve many of these issues. Where there is clear-cut evidence of marketplace morality in support of common practices, the practices are perfectly permissible ${ }^{101}$ even though they cannot be shown to enhance shareholder wealth. A good example is the widespread and long-standing acceptance of corporate philanthropy. Recognized at law and supported by well-established and recognized custom, philanthropy is unquestionably supported by an authentic norm. ${ }^{102}$ Despite the neoclassical economic claims that "spending money on corporate giving is wrong because it represents a waste of corporate assets," under this analysis. Presumably, this conclusion extends even to giving money to charity in times of operating losses. Ben \& Jerry's, following the practice of many other firms, gave $\$ 255,384$ to charity in 1994 , a year in which it incurred operating losses. ${ }^{104}$

More difficult is the case of the pluralistic manager who wishes to act on behalf of stakeholders on the basis of criteria other than that corresponding to clearly evident community morality. ${ }^{105}$ The business ethics literature suggests various criteria that might be used as a rationale for incorporating the interests of stakeholders into corporate decisionmaking. The most elaborate among the attempts at justification is based upon Kantian-derived stakeholder rights, particularly in the work of Evan and Freeman. ${ }^{106}$ Donaldson and Preston suggest, but do not detail, a foundation which is based upon property rights and which recognizes that stakeholders possess certain rights that may compete or interrelate with those possessed by shareholders. ${ }^{107}$ Earlier, Donaldson used a social contract theory as a means of "either replacing or augmenting the stakeholder model" in his treatment of international business ethics. ${ }^{108}$

Assume then that our pluralistic manager wishes to follow a Kantian analysis and in so doing acts in a manner that is inconsistent with both the assumed

101. The practices are not permissible, of course, if they violate manifest universal ethical norms or principles. See discussion infra of Principle 4.

102. See supra note 46 and accompanying text.

103. Rikki Abzug \& Natalie J. Webb, Rational and Extra-Rational Motivations for Corporate Giving: Complementing Economic Theory with Organizational Science, 41 N.Y.L. SCH. L. REV. 1035, 1035 (1997).

104. See Robert John Schulze, Book Note, Can This Marriage Be Saved? Reconciling Progressivism with Profits in Corporate Governance Laws, 49 STAN. L. REV. 1607, 1612 (1997).

105. Goodpaster incorporates a "Nemo Dat Principle" into his discussion of stakeholder synthesis and notes that investors cannot expect managers to act on their behalf in a manner "that would be inconsistent with the reasonable ethical expectations of the community." Goodpaster, supra note 19, at 68.

106. See William M. Evan \& R. Edward Freeman, A Stakeholder Theory of the Modern Corporation: Kantian Capitalism, in ETHICAL THEORY AND Business 75 (Tom L. Beauchamp \& Norman E. Bowie eds., 4th ed. 1993).

107. See Thomas Donaldson \& Lee E. Preston, The Stakeholder Theory for the Corporation: Concepts, Evidence, Implications, 20 ACAD. MGMT. REV. 65 (1995).

108. THOMAs Donaldson, THE ETHICS OF INTERNATIONAL Business 47 (1989). 
or actual wishes of the shareholders and the clearly evident marketplace morality. ${ }^{109}$ Such an approach is directly inconsistent with Principles Two and Three. A purposeful strategy of acting inconsistently with shareholder wealth maximization and marketplace morality is highly problematic.

On the other hand, marketplace morality may often be permissive rather than mandatory: The moral desires of people in markets relevant to the firm may support a system that allows managers to act on their own morality in many circumstances. Donaldson and I refer to this as the domain of "moral free space," in which one makes choices based upon community norms and personal values. ${ }^{110}$ The Merck example follows this approach. It was certainly neither legally nor morally mandatory that Merck develop and then give away Mectizan. But it was permissible on both counts. There is no evidence that Merck's actions were inconsistent with the marketplace morality of any of its relevant communities.

Principle 4. Act Consistently with Mandatory Hypernorms. There is one circumstance where following marketplace morality or the monotonic approach to shareholder wealth maximization is problematic: when the action violates what Donaldson and I have characterized as hypernorms. ${ }^{111}$ As discussed above, hypernorms are second-order norms, ${ }^{112}$ which serve to judge, and if necessary invalidate, local laws and local morality. Hypernorms "entail principles ... fundamental to human existence... . As such, we would expect them to be reflected in a convergence of religious, philosophical, and cultural beliefs." This is a high standard for a set of universal principles, and, presumably, the number and scope of such standards would be limited. Consider the example of selling carcinogen-contaminated pajamas in poor countries with insufficient background institutions to control the sale of such products. ${ }^{114}$ This strategy for disposing of the product may well increase shareholder wealth and overseas sales and may not violate clearly identifiable marketplace morality in the firm's relevant markets. On the other hand, the product is prohibited for sale in the United States and in Europe and is potentially harmful to the intended users. Taking De George's first principle-multinationals should do no intentional direct harm unless there is a cardinal overriding justification ${ }^{115}$ —as a hypernorm, it becomes the obligation of all organizations to recognize this principle in regard to stakeholders.

109. Presumably such cases will be rare; Kantian morality typically should be congruent with marketplace morality in relevant communities.

110. Donaldson \& Dunfee, Ties That Bind, supra note 82, at 38-41; Donaldson \& Dunfee, ISCT, supra note 82, at 260.

111. See supra Part III.B.

112. By second-order, we mean higher. Thus, first-order norms are judged by, and are inferior to, second-order norms.

113. Donaldson \& Dunfee, ISCT, supra note 82, at 265.

114. See Richard T. De George, Competing with InTEgrity in International Business 46 (1993).

115. See id. 
Again, Donaldson and I suggest the use of presumptions as a means of identifying relevant hypernorms. ${ }^{116}$ We suggest that

[i]f two or more of the following types of evidence confirm widespread recognition of an ethical principle, the decision maker should operate on the basis of a rebuttable presumption that it constitutes a hypernorm. The more types of evidence in support of a hypernorm, the stronger the presumption.

Evidence in support of a principle having hypernorm status:

(1) Widespread consensus that the principle is universal;

(2) Component of well-known global industry standards;

(3) Supported by prominent non-governmental organizations such as the International Labor Organization or Transparency International;

(4) Supported by regional government organizations such as the European Community, the OECD, or the Organization of American States;

(5) Consistently referred to as a global ethical standard by international media;

(6) Known to be consistent with precepts of major religions;

(7) Supported by global business organizations such as the International Chamber of Commerce or the Caux Round Table;

(8) Known to be consistent with precepts of major philosophies;

(9) Generally supported by a relevant international community of professionals, e.g., accountants or environmental engineers;

(10) Known to be consistent with empirical findings concerning universal human values; and

(11) Supported by the laws of many different countries.

Once having gone through these steps and having identified a presumptive hypernorm, the decision maker needs to consider whether evidence exists to overcome the presumption. If two or more of the following are found, then the presumption may be rebutted. However, the more types of evidence that support the presumption in favor of hypernorm status, the more types of evidence necessary to override the presumption.

Evidence countering the hypernorm presumption:

(1) Evidence from the presumptive list to the contrary, e.g., that the putative hypernorm principle does not represent a universal value;

(2) Evidence from the presumptive list in support of hypernorm status for a mutually exclusive principle; and

(3) A decision context such that applying the presumptive hypernorm could result in the violation of a widely recognized human right.

The marketplace morality approach places a high standard on those managers who wish to use a claim of stakeholder interests or general morality to act in a manner that is inconsistent with maximization of shareholder wealth. It requires that managers do more than just assert a consistency between their ac-

116. See DonALDSOn \& DunfeE, TIES ThAT BInD, supra note 82, at 60-61.

117. See id. 
tions and moral obligation. ${ }^{118}$ Instead, they should develop justifications in advance and stand ready to defend their stakeholder-based actions with evidence that supports the existence of hypernorms or objective evidence that validates marketplace morality.

\section{$\mathrm{V}$ \\ THE IMPLICATIONS OF MARKETPLACE MORALITY FOR LAW AND PUBLIC POLICY}

A major foundation for a marketplace morality-based analysis is the liberty of individuals to hold moral desires and to seek to implement them in their daily decisionmaking. For some people, implementing their moral desires is the most significant element of their lives. All people should have a maximal opportunity to act as they prefer in this domain. Individuals who act on the basis of their moral desires may implement them through a wide variety of economic, political, and social channels. They may vote consistently with their desires, lobby legislatures, boycott products, support social issue shareholder resolutions, buy or sell stock in certain firms, persuade friends and strangers to act in a similar way, and so on. Individuals also face many constraints in exercising their moral desires, particularly in the form of restrictive public policy and laws. Because there are many competing moral desires in political and social markets, this is to be expected. Those who find themselves blocked in one channel (for example, legal interpretations of corporate governance standards or restrictions limiting social issue shareholder resolutions) may turn to other channels (for example, lobbying for legislation or boycotts) as a means of giving effect to their preferences. Among the many channels susceptible to moral desires, the securities markets appear to be among the most open. One may buy and sell securities, at least for oneself, on the basis of whatever criteria one chooses.

As a general matter, supporting disclosure and individual choice in support of a marketplace of ideas is consistent with American traditions and ideals. As Oliver Wendell Holmes, dissenting in Abrams v. United States, put it so nicely:

$[\mathrm{T}]$ he ultimate good desired is better reached by free trade in ideas - that the best test of truth is the power of the thought to get itself accepted in the competition of the market and that truth is the only ground upon which their wishes safely can be carried out. That at any rate is the theory of our Constitution. ${ }^{119}$

The concept of marketplace morality is also consistent with the concept of reflexive law, which seeks to provide access to information and documentation

118. The emphasis on objective or manifest evidence is responsive to the concerns of critics such as Schulze who worry that the pluralistic proposals are "unworkable because they eliminate much of the guidance for managerial decision making. Under [the pluralistic] reforms, executives would be free to manage corporations based on caprice or bias. Moreover, the proposals leave no objective legal standard by which to judge and evaluate managerial performance." Schulze, supra note 104, at 1612 .

119. 250 U.S. 616,630 (1919). 
of statements toward supporting decisions by private actors. ${ }^{120}$ On the other hand, marketplace morality is not consistent with the idea of legal endorsement of inauthentic norms. For example, it is not clear that the implied contract for job security argued for by O'Connor, ${ }^{121}$ which would require directors to act as mediators between stockholders and employees, would meet the test of authentic norms.

Bowles suggests that the structure of markets and background institutions may have a significant effect on the preferences of those who participate in the markets or are subject to its institutions. ${ }^{122}$ This idea seems correct, and it has very significant implications. Preferences are not hard-wired to the individual such that they are independent of the external environment. Policies should be judged, in part, on the basis of their likely impact on citizens' moral desires and also their ability to give effect to those desires.

The extreme monotonic view, implemented through the business judgment rule, would have the effect of denying managers the ability to respond to marketplace morality and might, in certain circumstances, result in managers violating mandatory hypernorms. This view can be expected to influence the moral desires of the managers themselves. And, by deafening managers to marketplace morality, it would make it more difficult for individuals to assert their moral desires. These reasons, supported by the social contracts approach described above, require that the business judgment rule and other relevant policies be interpreted consistently with the four guiding principles:

(1) There is a presumption that all corporate actions must be undertaken to maximize shareholder wealth;

(2) Managers must respond to and anticipate existing and changing marketplace morality relevant to the firm that may have a negative impact on shareholder wealth;

120. See David W. Hess, Social Reporting: A Reflexive Law Approach to Corporate Social Responsiveness, 25 J. CORP. LAW (forthcoming 2000). See generally Eric W. Orts, Reflexive Environmental Law, 89 Nw. U. L. REV. 1227 (1995). Reflexive laws can be distinguished from "substantive" law on how they, as regulatory schemes, take responsibility for the outcome of social activity. Substantive law essentially mandates a certain outcome, while reflexive law preserves the freedom of regulated parties to reach their own outcomes but establishes procedures that will force those parties to "take account of various externalities." Gunther Teubner, Substantive and Reflexive Elements in Modern Law, 17 L. \& SOC. REV. 239, 255-57 (1983). Orts argues for environmental audits as a reflexive law alternative to substantive regulation (for example, command-control regulation) because they work toward institutionalizing environmental responsibility within corporations. See Orts, supra, at 1339. Similar to the National Environmental Policy Act, which requires agencies to prepare environmental impact statements, environmental audits operate on the assumption that the process of preparing an audit will promote responsible decisionmaking. See id. at 1272-75. Some of the key components of an environmental audit regulatory scheme are third-party verification and public disclosure. See id. at 1322-24. Similar to securities regulation, these requirements promote more efficient markets by giving the market participants more information. See id. at 1312.

121. Marleen A. O'Connor, Promoting Economic Justice in Plant Closings: Exploring the Fiduciary/Contract Law Distinction to Enforce Implicit Employment Agreements, in PROGRESSIVE Corporate LAW 235 (Lawrence E. Mitchell ed., 1995); see also Marleen A. O'Connor, The Human Capital Era: Reconceptualizing Corporate Law to Facilitate Labor-Management Cooperation, 78 CORNELl L. REV. 899 (1993).

122. See generally Bowles, supra note 57. 
(3) The presumption in Principle One may be rebutted where clear and convincing evidence exists that marketplace morality relevant to the firm would justify a decision that cannot be shown to maximize shareholder wealth directly; and

(4) Managers must act consistently with hypernorms (manifest universal norms and principles). ${ }^{123}$

VI

\section{CONCLUSION}

Analysis of the existence and nature of marketplace morality provides insights concerning the extent to which firm managers should consider the interests of stakeholders. Managers will more effectively satisfy their primary duty to shareholders when they respond to signals of significant moral preferences within capital, consumer, and labor markets relevant to the firm. Managers have a further obligation, based on a social contract, to act consistently with mandatory marketplace morality and manifest universal norms.

123. See supra Part IV.C. 